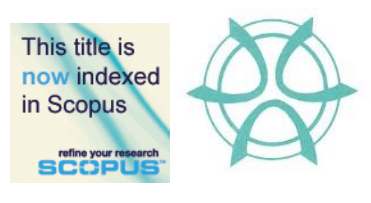

PLANNING MALAYSIA:

Journal of the Malaysian Institute of Planners

VOLUME 15 ISSUE 1 (2017), Page 209 - 220

\title{
DAYLIGHT CHARACTERISATION OF CLASSROOMS IN HERITAGE SCHOOL BUILDINGS
}

\author{
Maria Yohana Susan ${ }^{1}, \&$ Rani Prihatmanti ${ }^{2}$ \\ ${ }^{1,2}$ Interior Architecture Department, \\ CIPUTRA UNIVERSITY, INDONESIA
}

\begin{abstract}
This paper studies the daylight characteristics in selected high schools that are located in heritage-listed buildings. Heritage buildings were selected in this research due the problematic condition regarding the indoor illumination level after being adaptively reused. Based on the previous research, lighting in educational institution is a critical factor because poor lighting not only is detrimental to the occupants' visual comfort but also might lead to visual fatigue. To achieve the objectives of this paper, daylight level measurements and observation were conducted. The results show that the daylight that penetrates into the classrooms were below the standard due to many obstructions founded in both schools. Artificial lightings were used as a supplementary during the whole school hours since the daylight was not uniformly distributed. Thus it can be concluded that the inappropriate adaptive reusing heritage building indoor is significantly affecting the indoor light level and might lead to visual discomfort issues for students. The research findings as well as the suggestions have been delivered to the school management to overcome the issues founded.
\end{abstract}

Keyword: Daylight performance, visual comfort, heritage building, adaptive reuse, high schools

Date Received: $30^{\text {th }}$ April 2016

Date of Acceptance: $30^{\text {th }}$ October 2016 
Maria Yohana Susan, \& Rani Prihatmanti

Daylight Characterisation of Classrooms in Heritage School Buildings

\section{INTRODUCTION}

The issue regarding the effect of the indoor light level to the visual comfort has been highlighted since the last few years. This is also related with the green building trend where building occupants need to be comforted when they are indoor, be it is in an office, school, store or even at their own residence. Nowadays, green building rating tools have included the assessment on the Indoor Environmental Quality (IEQ) in order to obtain a healthy occupants and one of the assessments is to focus in on the visual comfort.

Based on the previous research, the indoor light level has a detrimental effect on the building occupants, including students. Indoor lighting is widely known to give a significant role in satisfying visual comfort as it is highly affecting students' satisfaction and their academic performance. Moreover, several studies have been conducted to highlight the lighting performance in learning environment (Yang, Becerik-Gerber \& Mino, 2013; Samani \& Samani, 2012; Axarli \& Tsikaloudaki, 2007; Benya, 2001).

To achieve good indoor lighting quality, it needs an appropriate planning. The lighting must accommodate the occupants' activity. However, there were some buildings were not meant to be built as its main purpose. Adaptively reused buildings are prone to cause discomfort to the occupants (Prihatmanti \& Bahauddin, 2011) and this is commonly found in heritage buildings which being reused into a different purpose or can no longer functioned with its original purpose. Therefore this research aims to study the lighting performance in high schools that is located in heritage-listed buildings.

\section{LITERATURE REVIEW}

Heritage building is an evidence of history. By conserving those buildings, it helps to understand the past and to contribute for the future generations. It can give the sense of continuity and belonging to the place where people live. One method for conserving heritage building is by adaptive reusing it. As stated in the Burra Charter (Australia ICOMOS, 1999), adaptive reuse is rehabilitating or renovating heritage buildings or structures for any uses other than the present uses. It involves no change to the culturally significant fabric, changes that are significantly reversible, or changes with minimal impact. Meanwhile, according to Bullen, adaptive reuse is known as one of the effective strategies to improve the sustainability of the existing building by lowering material, transport and energy consumption, as well as helps to reduce the pollution level (Bullen, 2007).

The changes of building function has made the building's IEQ level degrade, including the indoor lighting performance. It could be in the form of obstructing the windows, doors or any other openings in order to create more indoor spaces by applying full height partition. In order to maintain the IEQ level, there is a need to study the performance of the indoor light level based on the daylight that penetrates in the designated buildings. 
PLANNING MALAYSIA

Journal of the Malaysia Institute of Planners (2017)

The lighting performance is generally measured by the illuminance level (E), daylight factor (DF), and also the uniformity ratio. E or illuminance is a measure of the illumination of a surface (Szokolay, 2004). The illuminance level may vary for each room with different function. Illuminance level was produced by an overcast sky, and it strongly depends on the solar altitude angle behind the clouds. The overcast sky illuminance may vary in wide range limits. As the outdoor lighting conditions are highly variable, design can only be based on the worst conditions. However, the ratio between illuminance on a certain point indoors to the outdoors remains constant (Szokolay, 2004).

$$
\mathrm{DF}=\frac{\mathrm{E}_{\mathrm{i}}}{\mathrm{E}_{\mathrm{o}}} \times 100(\%) .
$$

Where,

$$
\begin{array}{ll}
\mathrm{Ei} & =\text { indoor illuminance } \\
\mathrm{Eo} & =\text { outdoor illuminance (vary from 20klx-130klx) } \\
\mathrm{DF} & =\text { Daylight Factor }
\end{array}
$$

The indoor illuminance for DF is measured in two measurement points. They are Main Measurement Moint (MMP) and Side Measurement Point (SMP) (Badan Standardidasi Nasional, n.d). MMP is observed in the middle of side walls, with the distance of $1 / 3$ from effective daylight aperture; while SMP is taken in the distance of $0.5 \mathrm{~m}$ from the side wall, in line with the MMP. Both of measurement points must be taken on the workplane height $(0.75 \mathrm{~m})$.

Uniformity ratio is used to study daylight distribution. Higher uniformity ratio means better daylight distribution. It is measured as the ratio of minimum workplane illuminance to average workplane illuminance. The maximum number for uniformity ratio is one (Yang, Becerik-Gerber \& Mino, 2013). Good daylighting for tropical climate is indicated by several parameters. As for classroom, the illumance level standard in tropical climate is approximately 200 lx (Rea, 2000). The standard for DF value on MMP point is $0.35 \mathrm{~d}$ (d=room depth) and on the SMP point is $0.2 \mathrm{~d}$ (Badan Standardidasi Nasional, n.d).

In order to supply maximum daylight into any room, uninterrupted visual line between the room inside and sky dome should be provided. In the past, buildings were designed to be adaptive with the local climate. The features of adaptive strategies in those buildings were purposely constructed to create users' thermal comfort. However, inappropriate design of the features could interrupt the visual line and reduce the daylight penetration into the room (Heerwagen, 2004). 
Maria Yohana Susan, \& Rani Prihatmanti

Daylight Characterisation of Classrooms in Heritage School Buildings

\section{METHODOLOGY}

\section{Selection of the Research Objects}

In Surabaya, there are number of heritage buildings that have been adaptively reused as schools that is located in heritage buildings. The research objects were selected based on the heritage significances. There were 2 schools selected in this study; all of them are the prominent private schools in Surabaya. Those are Santa Maria Senior High School and St. Louis Senior High School. These schools are listed as the national heritage building by the Surabaya City government regulation No. 5/2005. Since most of the heritage schools are expanding due to the increased numbers of students enrolled every year, this research was conducted in the classroom that is located only in the heritage building. However, due to the permission given by the schools, the survey was conducted during the last subject that is between 1 to 2 p.m. The typical classrooms from both schools can be seen in Figure 3 and 4.

\section{Research Objects Description}

\section{A. Santa Maria Senior High School}

This school is located in Raya Darmo Street Surabaya. This building is divided into the main and annexe building. The main building is considered heritage building since it was built in the 1920s. In this study, the studied class is located on the second floor, in the heritage wing, which is facing to the south. The east and west side of this building are facing open space, the north side is facing the Rever Academy building, and the south is where the annexe building located. The site illustration is shown in Figure 1.

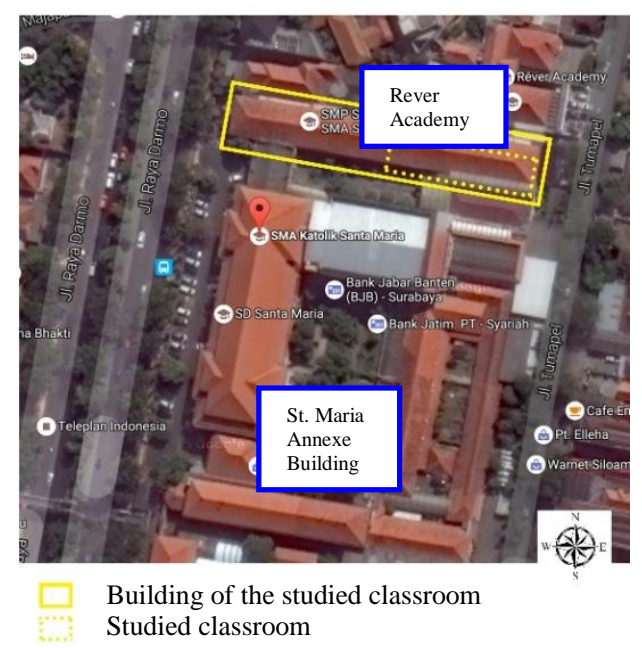

Figure 1 The Santa Maria School 
PLANNING MALAYSIA

Journal of the Malaysia Institute of Planners (2017)

The studied classroom is equipped with wooden desks and chairs. The floor is covered by grey-coloured terrazzo. The classroom is surrounded by brick walls, painted in matte white, with light green ceramics on the bottom-half of the wall. The ceiling height is approximately $3.5 \mathrm{~m}$ and painted in white. Based on the observation, there are no high reflectance materials in this classroom. The openings $(1.8 \times 1.0 \mathrm{~m}$ in size) are located on $1.8 \mathrm{~m}$ above the ground, on the north and south wall. The high ceiling and openings are the common characteristics of climate adaptation for buildings in the tropical climate. The obstructions for the openings come from the surrounding buildings, that is the annexe building (2storey high) and the Rever academy (single storey).

\section{B. St. Louis Senior High School}

This building is located at Polisi Istimewa street Surabaya. The building itself has a U-shape form. Similar with Santa Maria, this school also consist of heritage building and annexe building as the additional one. The building has open spaces on the north side and a courtyard on the south. The studied class is located on the second floor, in front part of this building, facing the north, i.e. the main road and parking spaces.

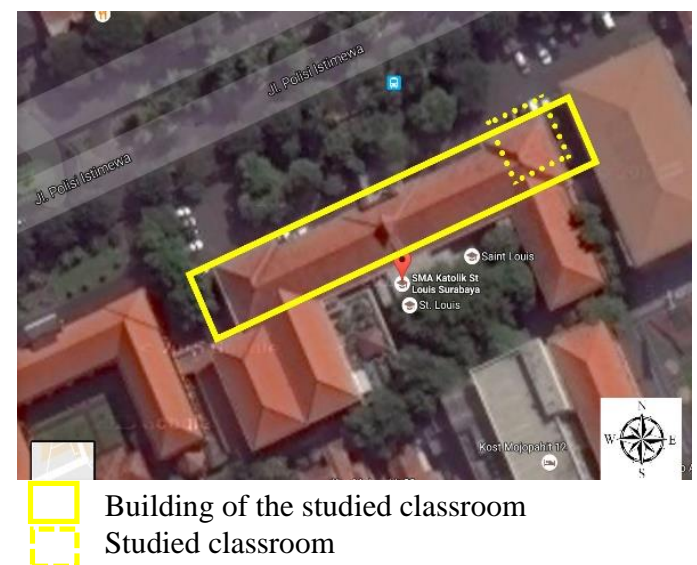

Figure 2 The St. Louis School

The furniture inside the classroom are made from wood, stained in dark colour. Dark grey terrazzo is used as the flooring material. Brick is used for wall material, and painted with green colour as its finishing. The $5 \mathrm{~m}$ ceiling is finished with white paint. Similar with the other building, most of the building fabrics and other materials are less reflectance. High openings are placed in north, east, and south wall. A door as an opening at the south wall is used for circulation access from the corridor to the classroom. The daylight comes mostly from the openings at the north and east side. The external obstruction comes from the vegetation on 
Maria Yohana Susan, \& Rani Prihatmanti

Daylight Characterisation of Classrooms in Heritage School Buildings

the open spaces, while internal obstruction comes from the internal shading as the window treatment.

\section{METHODOLOGY}

The objectives of this research is to assess the characteristics of daylight in heritage school buildings. Therefore the studied buildings need to be visually observed on the physical conditions (classroom and its surroundings) and the illuminance level needs to be measured quantitatively. The observations were taken on September 2015, when the sun is on the equinox position and in overcast sky. Surabaya is situated along the Equator $\left(7^{\circ} 15^{\prime} 55^{\prime \prime} \mathrm{S}\right.$ and $\left.112^{\circ} 44^{\prime} 33^{\prime \prime} \mathrm{E}\right)$, thus the amount of daylight is abundant throughout the year.

First, each classroom was divided into grids with $1.00 \mathrm{~m}$ to $1.20 \mathrm{~m}$ distances. The illuminance level for every grid's points were measured in workplane height $(0.75 \mathrm{~m})$ by using hand held light meter in daylight condition. The illuminance level measured was also for MMP and SMP. The daylight factor assessment was done by measuring indoor illuminance level and outdoor illuminance level at the same time, at the grid point that has been made.

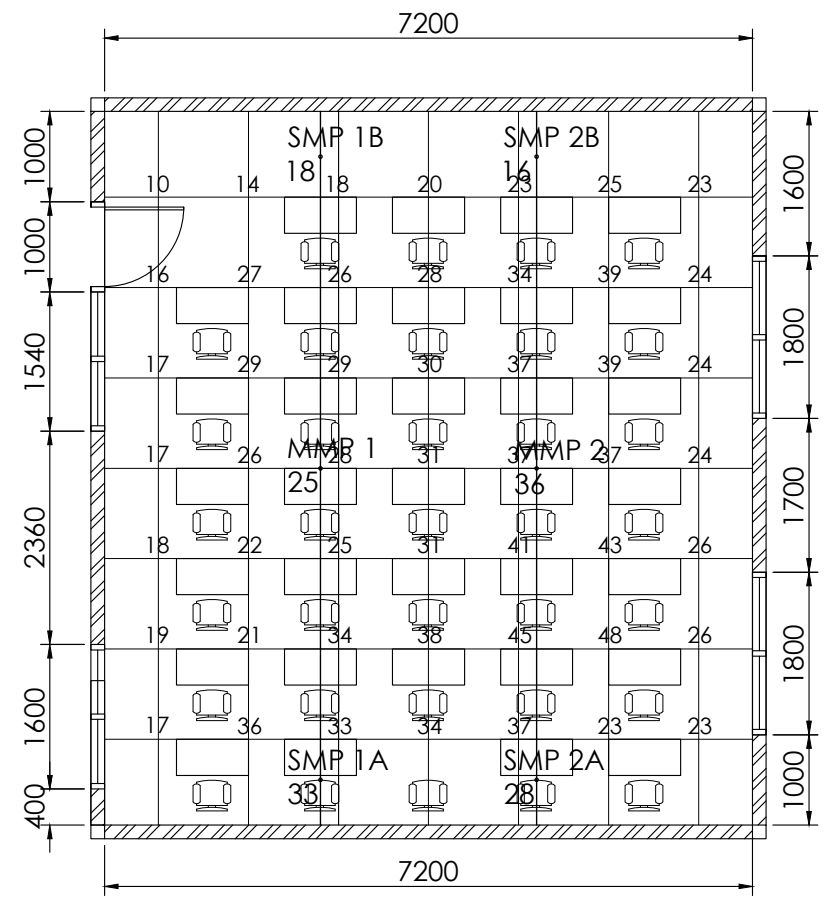

Figure 3 Illuminance Data of a Typical Classroom in Santa Maria 
PLANNING MALAYSIA

Journal of the Malaysia Institute of Planners (2017)

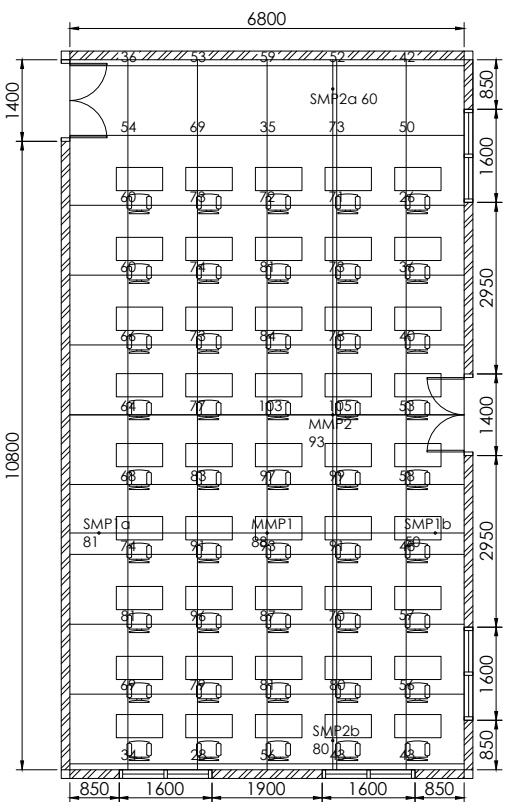

Figure 4 Illuminance Data of a Typical Classroom in St. Louis

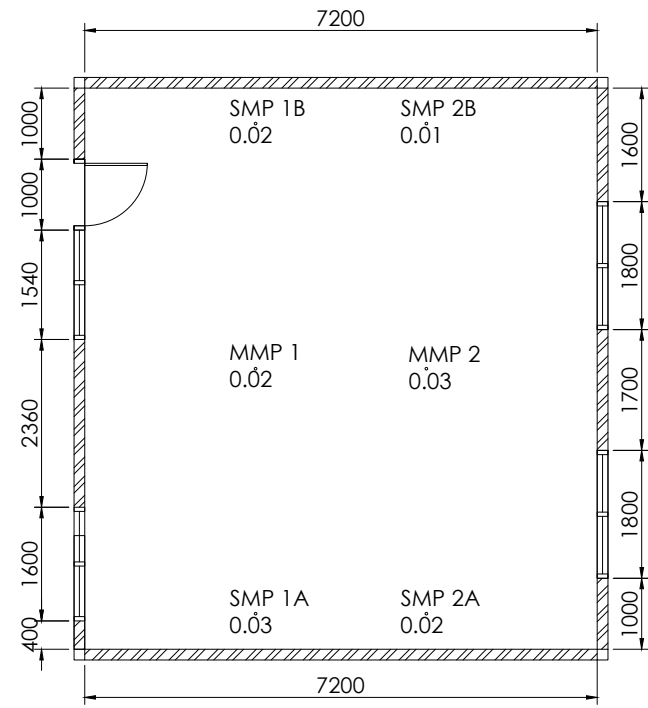

Figure 5 Daylight Factor of a Typical Classroom in Santa Maria

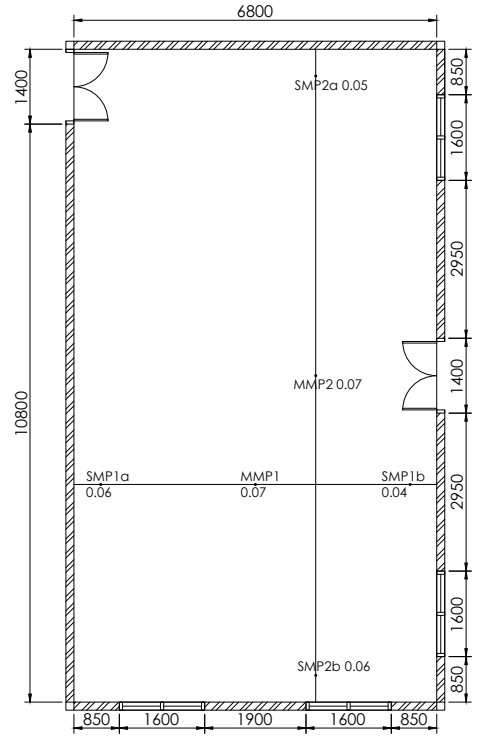

Figure 6 Daylight Factor of a Typical Classroom in St. Louis 
Maria Yohana Susan, \& Rani Prihatmanti

Daylight Characterisation of Classrooms in Heritage School Buildings

Figure 3 and 4 show the illuminance data for each classroom while the DF value for each measurement point can be seen in Figure 5 and 6. Thus, observation on the building and lighting parameters were conducted to answer the objectives of this research. To analyse the data that have been gathered previously, descriptive analysis was carried out as well as comparing with the references related.

\section{DISCUSSION AND CONCLUSION}

\section{Illuminance Level}

Analysis of illuminance level is started with the isocontour graphics as seen in Figure 7 and 8 . Higher illuminance level are shown with orange-red colour, while the blue colour shows the lower one. Both isocontour graphs show that higher illuminance levels are placed around the centre of the room. This result shows that lighting treatments on heritage building (high window, high ceiling, light painted) are successfully to bring the light deeper into the room. However, the numbers of illuminance level are still below the standard. Good illuminance level was analysed based on the IESNA requirements for classroom. The highest internal illuminance from both classrooms is only $105 \mathrm{~lx}$, that is below the standard $(200 \mathrm{~lx})^{9}$.

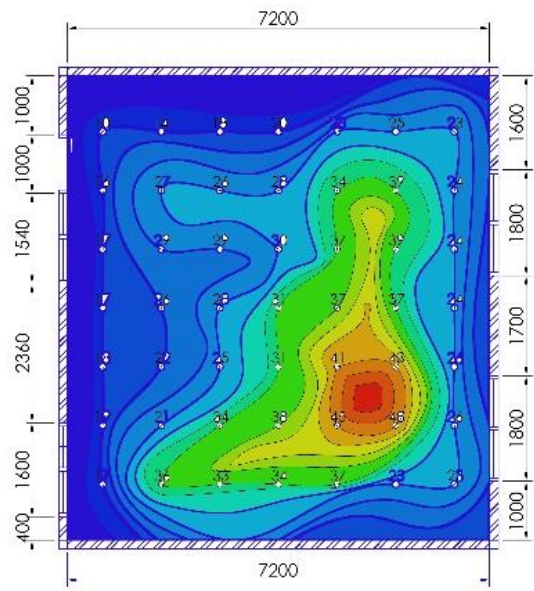

Figure 7 Isocontour of a Typical Classroom in Santa Maria

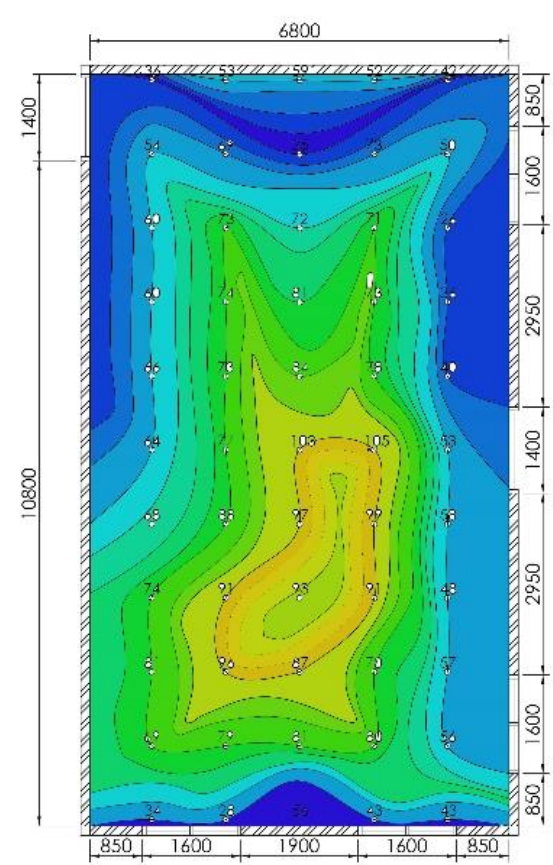

Figure 8 Isocontour of a Typical Classroom in St. Louis 


\section{Daylight Factor (DF)}

Beside illuminance level, DF was also considered in this research to indicate design effectiveness in bringing daylight into the indoor area. As mentioned previously, DF is the ratio between outdoor illuminance to indoor illuminance in the overcast sky. As seen in Figure 5 and 6, the DF value from both classes is between 0.01-0.07. This results are then compared to the DF value standard, and tabulated in Table 1 .

Table 1 Daylight Factor Level

\begin{tabular}{|c|c|c|c|c|}
\hline Name & DF actual & d (m) & MMP $=0.35 d$ & SMP 0.2d \\
\hline \multicolumn{5}{|c|}{ Santa Maria Senior High School } \\
\hline MMP 1 & 0.02 & \multirow{6}{*}{7.2} & 2.52 & \\
\hline SMP 1A & 0.03 & & & \multirow{2}{*}{1.44} \\
\hline SMP 1B & 0.02 & & & \\
\hline MMP 2 & 0.03 & & 2.52 & \\
\hline SMP 2A & 0.02 & & & \multirow{2}{*}{1.44} \\
\hline SMP 2B & 0.01 & & & \\
\hline \multicolumn{5}{|c|}{ St. Louis Senior High School } \\
\hline MMP 1 & 0.03 & \multirow{3}{*}{10.8} & 3.78 & \\
\hline SMP 1A & 0.04 & & & \multirow{2}{*}{2.16} \\
\hline SMP 1B & 0.02 & & & \\
\hline MMP 2 & 0.05 & \multirow{3}{*}{6.8} & 2.38 & \\
\hline SMP 2A & 0.04 & & & \multirow{2}{*}{1.36} \\
\hline SMP 2B & 0.03 & & & \\
\hline
\end{tabular}

Table 1 shows that all classrooms taken for this research have DF value below the standard level. As mentioned previously, uninterrupted visual line between room inside and sky dome should be provided in order to supply maximum daylight into any room. Some heritage features that need to be considered as the obstructions are the corridor, shading device, and surrounding building.

Both classrooms measured in this research are along the corridor. It is widely known that corridor could reduce the daylight penetration into the room. However, the DF value in St. Louis classroom is slightly higher since the classroom has higher ceiling level (6 meters) compare to the Santa Maria (4 meters). Higher ceiling gives chance for higher window level, which lead to higher chance for daylight penetration without any obstruction.

Since this research is conducted in tropical climate, shading device is one of climatic responsive strategies that needs to be considered. Appropriate design of shading device will contribute to better daylight condition. The overhangs could create higher illuminance level and distribution uniformity. However deep corridor make reflected sunlight cannot reach the room inside. Horizontal louvers with reflective metal materials could give more advantages. As shown in Figure 
Maria Yohana Susan, \& Rani Prihatmanti

Daylight Characterisation of Classrooms in Heritage School Buildings

9, horizontal louvers can reflect much more sunlight and contribute in giving higher daylight factor.

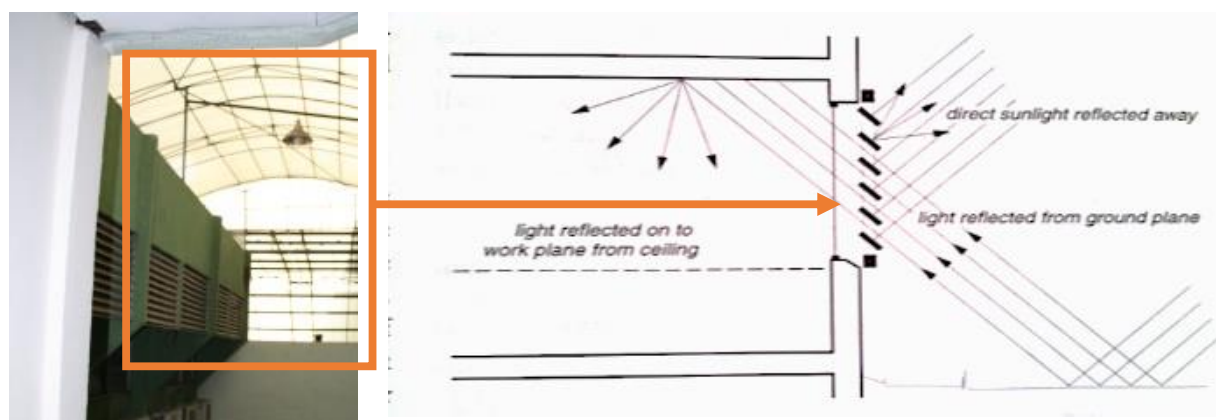

Figure 9 The Horizontal Louvers

Uninterrupted visual line can be provided if there is no obstruction from site contour, vegetation and surrounding building. Classroom observed in St. Louis has no surrounding buildings. However, the visual line of classroom observed in Santa Maria is obstructed by surrounding buildings.

\section{Uniformity Ratio}

Uniformity ratio is used to study the daylight distribution. Higher uniformity ratio means better daylight distribution, and the maximum value is one. Uniformity ratio for both classrooms are shown in Table 2 .

Table 2 Uniformity Ratio

\begin{tabular}{|l|l|l|l|}
\hline Name & $\begin{array}{l}\text { Minimum } \\
\text { WPI }\end{array}$ & Average WPI & $\begin{array}{l}\text { Uniformity } \\
\text { Ratio }\end{array}$ \\
\hline Santa Maria & 10 & 28 & 0.36 \\
\hline St. Louis & 26 & 77.84 & 0.33 \\
\hline
\end{tabular}

Theoretically, high ceiling, high window and appropriate placement of window are good strategies for creating better daylight distribution. But in this research, those strategies failed to create good daylight distribution. This can be seen from low uniformity ratio value. This is mainly due to the appropriate strategies that are not followed by sufficient daylight source. In the St. Louis the daylight source at one side of the rooms is obstructed by the corridor, while in Santa Maria it is obstructed by the corridor and surrounding buildings. 
PLANNING MALAYSIA

Journal of the Malaysia Institute of Planners (2017)

\section{CONCLUSION}

The result from the measurements shows that the indoor light levels in both classrooms were below the standard. The daylight was insufficient to provide good illuminance and the lights were not uniformly distributed. Thus it can be concluded that the inappropriate adaptive reusing heritage building indoor is significantly affecting the indoor light level and might lead to visual discomfort issues for the students.

Treatments for improvement are limited to the heritage building conservation rules. Therefore indoor treatments are the most preferred. Treatment in ceiling, wall and floor are suggested. Material with appropriate reflectance number will increase the illuminance level and DF value, while curved ceiling is suggested to obtain higher uniformity ratio.

The research findings as well as the suggestions have been delivered to the school management to overcome the issues discovered. However, there is a need in conducting research regarding the visual satisfaction in adaptively reused buildings, particularly in the school or office.

\section{ACKNOWLEDGEMENTS}

The authors would like to thank to the Indonesian State Ministry of the Research and Technology as the funding body under the grant scheme No. 050/SP2H/P/K7/KM/2016.

\section{REFERENCES}

Benya, J. R. (2001). Lighting for schools. National Clearinghouse for Educational Facilities. Retrieved from http://www.ncef.org/pubs/lighting.pdf

Badan Standardidasi Nasional (n.d). SNI 03-2396-2001.

Bullen, P. A. (2007). Adaptive reuse and sustainability of commercial buildings. Facilities, 25 (1/2), 20-31

Heerwagen, D. (2004). Passive and active environmental controls, informing the schematic design for buildings. Singapore: McGrawHill.

Axarli, K., \& Tsikaloudaki, K. (2007). Enhancing visual comfort in classrooms through daylight utilization. In Proceedings of Clima 2007 WellBeing Indoors. Helsinki, Finland.

Prihatmanti, R., \& Bahauddin, A. (2011). The indoor environmental quality of UNESCO listed heritage buildings, George Town, Penang. In Proceedings of 5th International Conference on Built Environment in Developing Countries. Penang, Malaysia.

Samani, S. A., \& Samani, S. A. (2012). The impact of indoor lighting on students' learning performance in learning environments: a knowledge internalization perspective. International Journal of Business and Social Science, 3(24), 127136.

Rea, M. S. (Ed.) (2000). The IESNA lighting handbook. Illuminating Engineering Society of North America.

Szokolay, S. V. (2004). Introduction to architectural science: the basis of sustainable 
Maria Yohana Susan, \& Rani Prihatmanti

Daylight Characterisation of Classrooms in Heritage School Buildings

design. Oxford: Elsevier.

Australia ICOMOS (1999). The Burra Charter. Victoria: Australia ICOMOS Incorporated.

Yang, Z., Becerik-Gerber, B., \& Mino, L. (2013). A study on student perceptions of higher education classrooms: impact of classroom attributes on student satisfaction and performance. Building and Environment, 70, 171-188. 